\title{
Ants (Hymenoptera: Formicidae) of Samoa ${ }^{1}$
}

\author{
Fames K. Wetterer ${ }^{2}$ and Donald L. Vargo ${ }^{3}$
}

\begin{abstract}
The ants of Samoa have been well studied compared with those of other Pacific island groups. Using Wilson and Taylor's (1967) specimen records and taxonomic analyses and Wilson and Hunt's (1967) list of 61 ant species with reliable records from Samoa as a starting point, we added published, unpublished, and new records of ants collected in Samoa and updated taxonomy. We increased the list of ants from Samoa to 68 species. Of these 68 ant species, 12 species are known only from Samoa or from Samoa and one neighboring island group, 30 species appear to be broader-ranged Pacific natives, and 26 appear to be exotic to the Pacific region. The seven-species increase in the Samoan ant list resulted from the split of Pacific Tetramorium guineense into the exotic $T$. bicarinatum and the native $T$. insolens, new records of four exotic species (Cardiocondyla obscurior, Hypoponera opaciceps, Solenopsis geminata, and Tetramorium lanuginosum), and new records of two species of uncertain status (Tetramorium cf. grassii, tentatively considered a native Pacific species, and Monomorium sp., tentatively considered an endemic Samoan form).
\end{abstract}

SAMOA IS AN ISLAND CHAIN in western Polynesia with nine inhabited islands and numerous smaller, uninhabited islands. The western four inhabited islands, Savai'i, Apolima, Manono, and 'Upolu, are part of the independent country of Samoa (formerly Western Samoa). The eastern five inhabited islands, Tutuila, Aunu'u, Ofu, Olosega, and Ta'u, are part of American Samoa, an unincorporated territory of the United States.

The ants of Samoa have been well studied compared with those of other Pacific

\footnotetext{
${ }^{1}$ Financial support was provided by American Samoa Community College; the Cooperative Research, Education, and Extension Service of the U.S. Department of Agriculture (CRIS Accession no. 164128, administered by the American Samoa Community College); Wheaton College; and Florida Atlantic University. Manuscript accepted 17 March 2003.

${ }_{2}$ Wilkes Honors College, Florida Atlantic University, 5353 Parkside Drive, Jupiter, Florida 33458 (phone: 561 799-8648; fax: 561-799-8602; E-mail: wetterer@fau.edu).

${ }^{3}$ Community and Natural Resources, American Samoa Community College, P.O. Box 5319, Pago Pago, American Samoa 96799.
}

Pacific Science (2003), vol. 57, no. 4:409-419

(C) 2003 by University of Hawai'i Press

All rights reserved island groups, prompting Wilson and Taylor (1967:4) to feel "confident that a nearly complete faunal list could be made for the Samoan Islands." Samoa is of particular interest because it is one of the easternmost Pacific island groups with a substantial endemic ant fauna. Wilson and Taylor (1967:1) concluded that "few if any ant species are native to the islands east of Rotuma, Samoa, Tonga, and New Zealand. This part of Polynesia has been populated by tramp species" (i.e., species that associate with humans and are spread by human commerce).

In this study, we combine published, unpublished, and new records from Samoa, increasing the list of ants known from Samoa to 68 species.

\section{Publisbed Records}

Wilson and Taylor (1967) summarized published records for ants from Samoa. In addition, they reported new ant specimens collected in Samoa by Sweeney and Zimmerman in 1940, by Woodward in 1956, and by Taylor in 1962. Wilson and Taylor (1967) indicated (in their table 2) that there were 59 ant species recorded from Samoa. Wilson and Hunt (1967), however, listed 61 ant species from Samoa, and we used this second list as a 
starting point, with one exception. We used Pacbycondyla insulana (Mayr) (formerly Ectomomyrmex insulanus Mayr) listed by Wilson and Taylor (1967), instead of Ectomomyrmex samoanus (a name not found in Bolton 1995; apparently a typographical error) listed by Wilson and Hunt (1967).

Wilson and Hunt's (1967) list increased to 62 when Bolton (1977) separated Pacific specimens of two taxa that Wilson and Taylor (1967) had synonymized, Tetramorium guineense (Bernard) and Tetramorium guineense macrum Emery, recognizing the former as an exotic from Southeast Asia, Tetramorium bicarinatum (Nylander), and the latter as a Pacific native, Tetramorium insolens (Smith). Bolton (2000) reclassified Samoan specimens listed by Wilson and Taylor (1967) as Smithistruma dubia Brown [now Pyramica karawajewi (Brown)] as a new species, Pyramica epipola Bolton. This species is known only from Samoa, but Bolton (2000) thought that it was likely to occur elsewhere in the Pacific.

The 62 ant species with specimens documented in Wilson and Taylor (1967) are listed in Tables 2 and 3 (updated taxonomy from Bolton 1995, 2000). The following 12 species names differ from those used by Wilson and Taylor (1967) (in parentheses): Anoplolepis gracilipes (Smith) (A. longipes), Cerapacbys biroi Forel (Syscia silvestrii), Monomorium liliuokalanii Forel ( $M$. minutum), Monomorium sechellense Emery (M. fossulatum), Pacbycondyla insulana (Ectomomyrmex insulanus), Pacbycondyla stigma (Fabricius) (Tracbymesopus stigma), Pyramica epipola (Smitbistruma dubia), Pyramica membranifera (Emery) (Trichoscapa membranifera), Rogeria stigmatica Emery ( $R$. sublevinodis), Strumigenys emmae (Emery) (Quadristruma emmae), Tetramorium bicarinatum ( $T$. guineense), and Tetramorium insolens (T. guineense).

Dlussky $(1994 a, b, c)$ reported on ants collected during a 1980 visit to Samoa by the Soviet research ship Kallisto, adding a new record of one additional species, Hypoponera opaciceps (Mayr), raising the number of Samoan ants to 63 species. Although not included in his paper, G. M. Dlussky (pers. comm.) provided us with collection information for these ants (see Results).

\section{Published Records Excluded from Wilson and Hunt's (1967) List}

Kami and Miller (1998) compiled a checklist of Samoan insects that included 78 ant taxa, 16 more than the list of 62 in the preceding section derived from records in Wilson and Taylor (1967). In this extremely useful summary of Samoan records, Kami and Miller (1998:i) stated that "in some cases it is clear that the names were misapplied," and this appears to be true of a number of ant records. Of the 16 additional taxa on Kami and Miller's (1998) list, eight were duplicate records, seven were records that Wilson and Taylor (1967) considered but dismissed as doubtful, and one taxon Wilson and Taylor (1967) did not consider (Table 1). Only two of these 16 species [Solenopsis geminata ( $\mathrm{Fa}-$ bricius) and Tetramorium lanuginosum Mayr] are known from elsewhere in Polynesia, and both have been subsequently found in Samoa (see Results).

DUPlicate records. Kami and Miller's (1998) checklist included eight pairs of duplicate records, where Samoan specimens were identified as one species, then reidentified as another, but both names were included on the list (name considered valid for Samoan specimens in parentheses): Camponotus conithorax Emery (=C. flavolimbatus Viehmeyer), Camponotus novaebollandiae Mayr $(=C$. cbloroticus Emery), Camponotus rufifrons leucopus Emery (=C. flavolimbatus), Cerapacbys typhlus (Roger) (=C. biroi Forel), Hypoponera convexiuscula (Forel) $[=H$. confinis (Roger)], Monomorium monomorium Bolton (=M. liliuokalanii), Odontomachus baematodus (L.) $(=O$. simillimus F. Smith), and Pbeidole teneriffana Fore $[=P$. megacephala (Fabricius)].

Wilson and Taylor (1967) reclassified Camponotus specimens from Samoa previously identified as $C$. novaebollandiae, $C$. conitborax var. nautarum, and $C$. rufifrons leucopus: the first as $C$. chloroticus and the other two as $C$. flavolimbatus. Taylor (1967a:91) wrote that Syscia typbla Roger (now Cerapachys typhlus) was "known under various names from China, Nepal, Okinawa, Hawai'i, Samoa and Puerto Rico (Wilson and Taylor mss)." Wilson and Taylor (1967), however, used the 
TABLE 1

Previously Published Samoan Ant Records Listed in Kami and Miller (1998), but Not Included in Wilson and Hunt (1967)

\begin{tabular}{|c|c|c|c|c|}
\hline \multirow[b]{3}{*}{ Species } & \multicolumn{3}{|c|}{ Known Regional Range } & \multirow{3}{*}{$\begin{array}{c}\text { Status of Samoan } \\
\text { Records Based on } \\
\text { Wilson and Taylor } \\
\text { (1967) }\end{array}$} \\
\hline & \multicolumn{2}{|c|}{ West Pacific ${ }^{a}$} & \multirow{2}{*}{$\frac{\text { Polynesia }^{b}}{\text { WSTNCFH }}$} & \\
\hline & AI & MCSNVF & & \\
\hline Camponotus conitborax Emery & -- & $----V-$ & -?----- & $=C$. flavolimbatus \\
\hline Camp. flavomarginatus Mayr & -- & ------ & $-?-----$ & Doubtful \\
\hline Camp. novaebollandiae Mayr & $\mathrm{A}-$ & $--\mathrm{SN}--$ & $-?-----$ & $=C$. cbloroticus \\
\hline Camp. rufifrons leucopus Emery & -- & $---\mathrm{N}--$ & $-?-----$ & $=C$. flavolimbatus \\
\hline Cerapacbys typhlus (Roger) & -- & ------ & $-?-----$ & $=C$. biroi \\
\hline Euprenolepis stigmatica (Mann) & -- & $--\mathrm{S}---$ & $-?-----$ & Doubtfil \\
\hline Hypoponera convexiuscula (Forel) & $\mathrm{A}-$ & ------ & $-?-----$ & $=H$. confinis \\
\hline Iridomyrmex rufoniger (Lowne) & $\mathrm{A}-$ & ------ & $-?-----$ & Probably erroneo \\
\hline Monomorium monomorium Bolton & -- & ------ & $-?-----$ & $=M$. liliwokalanii \\
\hline Odontomachus baematodus (L.) & -- & ------ & $-?-----$ & $=O$. simillimus \\
\hline Oecopbylla smaragdina (Fabricius) & AI & $-\mathrm{S}_{-}---$ & $-?-----$ & Doubtful \\
\hline Pbeidole tenteriffana Forel & -- & ------ & $-?-----$ & $=P$. megacepbala \\
\hline Rbytidoponera metallica (Smith) & $A-$ & $---\cdots$ & $-?-----$ & Probably erroneo \\
\hline Solenopsis geminata (Fabricius) & $\mathrm{AI}$ & MCSN-F & $-\mathrm{ST}-\mathrm{CFH}$ & Not considered \\
\hline Tapinoma wheeleri (Mann) & -- & ----- & 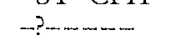 & Not from Samoa \\
\hline Tetramorium lannginosum Mayr & $\mathrm{AI}$ & MCS--- & WST-CF- & Ephemeral \\
\hline
\end{tabular}

"A, Australia; I, Indomalaysia; M, Mariana Islands; C, Caroline Islands; S, Solomon Islands; N, New Caledonia; V, Vanuatu; F, Fiji. ${ }^{b}$ W, Wallis and Futuna; S, Samoa; T, Tonga; N, Niue; C, Cook Islands; F, French Polynesia; H, Hawai ${ }^{i}$.

name Syscia silvestrii Forel (now Cerapachys biroi) for specimens from Nepal, Okinawa, Hawaici, and Samoa, writing that W. L. Brown Jr. had examined the type of C. typhus and determined that it was a separate species. Wilson and Taylor's (1967) figure for Syscia silvestrii is labeled as Syscia typbla, an error reflecting their previous identification. Wilson and Taylor (1967) synonymized the Samoan form of Hypoponera convexiuscula (described as Ponera trigona convexiuscula nautarum Forel), making it a junior synonym of Hypoponera confinis. Bolton (1987) established Monomorium monomorium as a replacement name for Monomorium minutum Mayr. Bolton (1987), however, examined Pacific samples (from Samoa and Hawai $i$ ) that had been assigned to Monomorium minutum and found that they were a separate species, Monomorium liliuokalanii. Many authors listed Odontomachus baematodus from Pacific locales, but Wilson and Taylor (1967:32) assigned all Polynesian Odontomacbus specimens to $O$. simillimus, writing " $O$. simillimus is a native Indo-Australian species distinct from the
Neotropical O. haematodus." Santschi (1919) listed Pbeidole teneriffana (identified by G. Arnold), but not $P$. megacephala, from Samoa, an opinion he repeated in Buxton and Hopkins (1927). But Santschi (1928) did not list this species, indicating that he dismissed the earlier identification. Wilson and Taylor (1967) concluded that $P$. teneriffana listed by Santschi (1919) was actually P. megacephala.

DoubTful RECORDs. Wilson and Taylor (1967) considered "very doubtful" the Samoan record of Paratrechina stigmatica Mann [now Euprenolepis stigmatica (Mann)], a Solomon Island endemic, based on a single "incomplete" specimen from "Upolu (Santschi 1928) (Table 1). Wilson and Taylor (1967: 100) questioned Mayr's (1876) record of the Australian Rhytidoponera metallica (Smith) as a "probably erroneous record," speculating "if the labeling was correct in the first place, the Samoan metallica population was undoubtedly introduced from Australia, and was probably ephemeral in nature" (p. 21). Wilson and Taylor (1967:80) suspected that Zatapinoma wheleri Mann [now Tapinoma 
wheeleri (Mann)], a species known only from a single soldier listed as "taken in quarantine at Honolulu on plants from Samoa" (Mann 1935), actually did not originate in Samoa. Wilson and Taylor (1967:70) listed Triglyphotbrix striatidens (Emery) (now Tetramorium lanuginosum Mayr), collected by Swale labeled "Apia $1000 \mathrm{ft}$ " with no date, as "based on a single worn specimen taken many years ago: the species has not been recorded from the islands since, despite intensive collecting" (specimen housed at the American Museum of Natural History, see Results). Finally, Wilson and Taylor (1967) listed three other species with records from Samoa in an appendix of doubtful records. All three were species that were listed but apparently not examined by Santschi $(1919,1928)$ : Camponotus flavomarginatus Mayr, Iridomyrmex rufoniger (Lowne), and Oecopbylla smaragdina (Fabricius).

NOT CONSIDERED. Wilson and Taylor (1967) did not consider one valid taxon with a published record from Samoa (Table 1). Santschi $(1919,1928)$ listed (but apparently did not examine) Solenopsis geminata rufa (Jerdon) (now Solenopsis geminata) collected on 'Upolu by H. Swale and identified by G. Arnold.

\section{MATERIALS AND METHODS}

In addition to published records of ants from Samoa, we searched for undocumented ant specimens from Samoa in the collections of several museums: the National Museum of Natural History (NMNH) in Washington, D.C.; the American Museum of Natural History (АмNн) in New York; and the Museum of Comparative Zoology (MCz) in Cambridge, Massachusetts.

From 13 June to 12 August 1995, J.K.W. collected ants on eight inhabited islands: Savai'i, 'Upolu, Tutuila, Ta'u, Ofu, Alleges, Manono, and Aunu'u, and on eight smaller uninhabited islands: Namu'a (east of 'Upolu), Nu'usetoga (north of Tutuila), Nu'utele (west of Ofu), Tauga (also called Camel Rock or Ma'a Kamela, south of Tutuila), Futi (part of Fatumafuti, south of Tutuila), Albatross Island (north of 'Upolu), Nu'upulu (east of
Savai $i$ ), and a very small sand islet next to Nu'usetoga (north of Tutuila). (Note: there is a second small Samoan island also named Nu'utele, east of 'Upolu.) J.K.W. also collected ants on a ferry between 'Upolu and Savai'i. J.K.W. collected by visual search, turning over rocks and logs, stripping the bark off logs, and breaking the logs apart.

From 1998 to 2002, D.L.V. collected ants on Tutuila, Ta'u, and Taputapu (west of Tutuila).

\section{RESULTS}

From museum and new specimens, we added five additional species to the list of Samoan ants: Cardiocondyla obscurior Wheeler, Monomorium sp., Solenopsis geminata, Tetramorium cf. grassii, and Tetramorium lanuginosum, raising the number to 68 species. We present Samoan records here for eight ant species not included on Wilson and Hunt's (1967) list (one species split into two plus six newer records).

\section{Cardiocondyla obscurior Wheeler}

Savai'i: Asau, in dead branches and strays (J.K.W., 10 July 1995); up forestry road near Mt. 'Elietoga, in logs and under moss on logs (J.K.W., 11-12 July 1995).

'Upolu: Tiavi Falls overlook, in dead branches (J.K.W., 5 July 1995).

Tutuila: Mapusaga, strays around house (J.K.W., 16 June 1995); northwest side of Mt. Matafao, on and in tree (J.K.W., 22 July 1995).

Albatross Island (north of 'Upolu): top of island $15 \mathrm{~m}$, in $\log$ (J.K.W., 30 June 1995 ).

Cardiocondyla obscurior is an Old World tramp species that may be a recent arrival in Samoa. This species is often misidentified as another tramp, C. wrougbtonii, but may be distinguished from that species based on coloration and discriminant function analysis (B. Seifert, unpubl. data). These two species also show ecological differences, with $C$. obscurior being more arboreal and $C$. wroughtonii more subterranean (S. Cover, pers. comm.). Cardiocondyla obscurior has not been recognized previously from the Pacific. However, B. Seifert (pers. comm.) has also identified 
specimens from Hawai' $i$ and the Mariana Islands as belonging to this species.

Other authors have recorded Cardiocondyla wrougbtonii in Hawai' $\mathrm{i}$, including Wilson and Taylor (1967) and Wetterer (1997a). The specimens collected by Wetterer (1997a), however, turned out to be a mix of $C$. wroughtonii and C. obscurior (B. Seifert, pers. comm.). Recent surveys have also recorded C. wroughtonii in the Cook Islands (Morrison 1997) and French Polynesia (Morrison 1996a,b, 1997). It seems likely that some of these specimens are actually $C$. obscurior.

\section{Hypoponera opaciceps (Mayr)} 1980).

'Upolu: Faisefooa (G. M. Dlussky, August

Ta'u: Tunoa Ridge, under moss on cliff and under rocks (J.K.W., 28 July 1995).

Aunu'u: Ma'ama'a Cove, oceanside strays (J.K.W., 19 June 1995).

Apolima: no site (G. M. Dlussky, August 1980).

Dlussky (1994a) reported this ant from Samoa but did not include the collection data given here. Hypoponera opaciceps is considered a pantropical tramp species originating in the neotropics. It is often overlooked because it is generally subterranean.

Wilson and Taylor (1967) listed this ant in Hawai' $i$ and French Polynesia, and more recent surveys have also found this species in Tonga (Wetterer 2002), the Cook Islands (Morrison 1997), and French Polynesia (Morrison 1996a,b, 1997).

\section{Monomorium sp.}

Aunu'u: swamp by Pala Lake, in $\log$ (J.K.W., 15 June 1995).

These specimens did not match any Monomorium known from Samoa or surrounding island groups. We tentatively consider it an endemic Samoan form, despite the fact that we found these ants only on a small, highly disturbed island. This is not the same species as the undescribed Monomorium from Tonga listed by Wetterer (2002). Brian Heterick, at the California Academy of Sciences, is currently evaluating the status of both these Monomorium species.
Solenopsis geminata (Fabricius)

Tutuila: Fagaalu Beach (D.L.V., 20 May 2002).

Santschi (1928) listed the tropical fire ant, Solenopsis geminata, from Samoa, but it seems unlikely that this very conspicuous ant could have maintained a population in Samoa for the past 70 yr without being recorded. Our new record may represent a recent invasion.

Solenopsis geminata, native to the neotropics, is an invasive pest in many parts of the Pacific, including the neighboring archipelagos of Fiji, Tonga, and the Cook Islands. Whether this ant becomes a pest in Samoa remains to be seen.

\section{Tetramorium bicarinatum (Nylander)}

Savai'i: Asau (N. L. H. Krauss, March 1977 , in AMNH); $1 \mathrm{~km}$ above Vaiola, $300 \mathrm{~m}$, in log (J.K.W., 11 August 1995); Salelologa by road (J.K.W., 12 August 1995); Maota, under moss on $\log$ (J.K.W., 12 August 1995).

'Upolu: Apia (H. Swale, in Bolton 1977); Apia (P. A. Buxton \& Hopkins, 1946, in Bolton 1977); Malololelei (P. A. Buxton, 1946, in Bolton 1977); Afiamalu (O. H. Swezey, 1940, in Bolton 1977); Tapatapao (O. H. Swezey, 1940, in Bolton 1977); Tapatapao (E. C. Zimmerman, 1940, in Bolton 1977); Mulivai (N. L. H. Krauss, January 1978, in AMNH); Apia (N. L. H. Krauss, February 1979, in AMNH).

Tutuila: Pago Pago (W. M. Wheeler, in Bolton 1977); no site (E. C. Zimmerman, 1940, in Bolton 1977); Mapusaga, strays and under rocks around houses (J.K.W., 16 June 1995); Mapusaga, forest, in logs and epiphytes (J.K.W., 19-21 June 1995); Larson's Bay, strays on beach (J.K.W., 17 June 1995); Utulei (J.K.W., 21 June 1995); Mt. Alava, $495 \mathrm{~m}$, under moss on logs and trees (J.K.W., 8 August 1995).

Ta'u: above Faleasao, in yard, $100 \mathrm{~m}$, strays (J.K.W., 24 July 1995); Fitiuta, in logs and strays (J.K.W., 25 July 1995); Tunoa Ridge, 50 m, in logs (J.K.W., 25 July 1995); Tunoa Ridge, 110 m, strays (J.K.W., 25 July 1995); Tunoa Ridge, $250 \mathrm{~m}$, under moss on cliff (J.K.W., 28 July 1995); Si'u, in $\log$ on beach (J.K.W., 27 July 1995).

Ofu: top of Mt. Tumutumu, $462 \mathrm{~m}$, 
around concrete platform (J.K.W., 31 July 1995).

Olosega: above Lamaga Point, $100 \mathrm{~m}$, strays (J.K.W., 1 August 1995); Lalomano, in banana field (J.K.W., 1 August 1995).

Aunu'u: SW island, between town and school, strays on vegetation (J.K.W., 19 June 1995).

Namu'a: island edge, strays (J.K.W., 28 June 1995).

Nu'utele: near the top $50 \mathrm{~m}$, in logs (J.K.W., 3 August 1995).

Albatross Island: top of island, in logs (J.K.W., 30 June 1995).

Ferry between 'Upolu and Savai'i (J.K.W., 9 July 1995).

Rose Island: (L. P. Schultz, 15 June 1939, in NMNH).

This species has no doubt been established in Samoa for at least 50 yr. Bolton (1977) listed several Tetramorium bicarinatum specimens from Samoa, including some listed by Wilson and Taylor (1967) as Tetramorium guineense specimens $\left(^{*}=\right.$ in Wilson and Taylor 1967). Tetramorium bicarinatum is considered exotic to the Pacific region but is now widespread throughout the area (Bolton 1977).

\section{Tetramorium cf. grassii}

Nu'upulu: strays on vine (J.K.W., 13 July 1995).

Tetramorium grassii is considered native to South Africa, and the only previous Pacific records come from New Zealand. The Samoa specimens matched specimens collected in New Zealand well, but did not perfectly match specimens from South Africa. Thus, we believe the Pacific form may be a separate species, which we tentatively consider native to the Pacific, despite having found it only on a very small and very disturbed island.

\section{Tetramorium insolens (Smith)}

Savai'i: Palauli (N. L. H. Krauss, February 1955, in $\mathrm{MCZ}^{*}$ ); Asau (N. L. H. Krauss, March 1977, in AMNH); above Vaiola, in $\log$ (J.K.W., 11 August 1995).

'Upolu: Afiamalu (E. C. Zimmerman, June 1940, in $\mathrm{MCZ}^{*}$ ); Malololei Road (E. C. Zim- merman, July 1940, in $\mathrm{MCZ}^{*}$ ); no site (Buxton \& Hopkins, 1946, in Bolton 1977).

Tutuila: Fagasa (T. Fulloway, August 1930, in Bolton 1977*); Pago Pago (E. C. Zimmerman, 8 August 1940, in $\mathrm{MCZ}^{\star}$ ); top of Mt. 'Alava, under moss on logs and trees (J.K.W., 8 August 1995).

Santschi (1928) and Wheeler (1935) listed Tetramorium guineense macrum (now Tetramorium insolens) from Samoa based on specimens collected by Bryan in 1924. Bolton (1977) listed several Tetramorium insolens specimens from Samoa, including some listed by Wilson and Taylor (1967) as Tetramorium guineense specimens ${ }^{*}=$ in Wilson and Taylor 1967).

Tetramorium insolens is considered native to the Pacific region. In Polynesia, this species is also known from Tonga (Wetterer 2002), Niue (Taylor 1967b), and Wallis and Futuna (Bolton 1977).

\section{Tetramorium lanuginosum Mayr}

Savai i: Salelologa plantation, under rocks (J.K.W., 12 August 1995).

"Upolu: "Apia $1000 \mathrm{ft}$ " (H. Swale, no date, in AMNH); Lauli'i (T. E. Woodward, January 1956 , in $\mathrm{MCZ}$ ).

Tutuila: Mapusaga, under rocks around house (J.K.W., 16 June 1995); Mapusaga forest, in logs and strays (J.K.W., 18, 20, \& 21 July 1995); PX by airport, strays (J.K.W., 17 June 1995); Utulei, strays in Rainmaker Hotel garden (J.K.W., 21 July 1995).

Ofu: Fatuana Point, strays on trees (J.K.W., 30 July 1995).

Aunu'u: dock area at tuna bait and strays (J.K.W., 15 \& 19 June 1995); $0.5 \mathrm{~km} \mathrm{E} \mathrm{of}$ school, sweep sample of grass (J.K.W., 19 June 1995).

Namu'a: island edge, strays (J.K.W., 28 June 1995).

Nu'utele: east shore, strays on shore (J.K.W., 3 August 1995).

Nu'usetoga: south cliffs, strays on rocks (J.K.W., 22 June 1995).

Tauga: under rocks and grass roots (J.K.W., 21 June 1995).

Albatross Island: top of island, in logs (J.K.W., 30 June 1995). 
Tetramorium lanuginosum is considered a pantropical tramp. Wilson and Taylor (1967) dismissed Swale's record, but we found another early record, from 1956, and we also collected it on nine different islands, primarily in highly disturbed areas. This suggests that $T$. lanuginosum has been in Samoa for many years but perhaps recently expanded its populations.

Wilson and Taylor (1967) listed this ant (as Triglyphotbrix striatidens) in Polynesia from the Cook Islands and the Line Islands. Additional Polynesian records for this species now include Wallis and Futuna (Bolton 1976), Tonga (Wetterer 2002), and French Polynesia (Morrison 1997).

\section{DISCUSSION}

There are now reliable records for 68 ant species from Samoa, more than any other island group in Polynesia. Of these 68 species, 12 species are known only from Samoa or from Samoa and one neighboring island group, 30 species appear to be broaderranged Pacific natives, and 26 appear to be exotic to the Pacific region (Tables 2 and 3).

\section{Local Endemic Ant Species in Samoa}

Of the 12 local endemic ant species in Samoa (Table 3), 10 are known only from Samoa and two are known only from Samoa and one neighboring island group: Vollenhovia samoensis Mayr (also Tonga [Wetterer 2002]) and Strumigenys mailei Wilson \& Taylor (also Fiji [Wilson and Taylor 1967]).

\section{Native Pacific Ant Species in Samoa}

Following the classification system of Wilson and Hunt (1967), 30 of the ant species known from Samoa are wide-ranging Pacific natives, though it is not possible to determine reliably which of these species are actually native to Samoa (i.e., predating humans) and which are more recent arrivals from other parts of the Pacific. Two of these species had been classified by Wilson and Hunt (1967) as Samoan endemics, but now are known to have wider ranges. Camponotus navigator Wilson has also been found on Pohnpei in the Caroline Islands, Micronesia (R. Clouse and M. Deyrup, unpubl. data), and Ponera loi Taylor was collected in the Mariana Islands, Micronesia [=Ponera sp. A in Terayama et al. (1994) and J.K.W. and Bourquin, unpubl. data].

Four ant species that are native to the western Pacific region have invaded other parts of the world. One such "Pacific-native tramp" is Tecbnomyrmex albipes (Smith), the "white-footed" ant, which is now found as an exotic in many areas including New Zealand, Hawaiti, California, Florida, South Africa, India, China, Madagascar, and Saudi Arabia (Wilson and Taylor 1967, Wetterer 1997a, 1998, McGlynn 1999). In addition, Tetramorium tonganum Mayr is an exotic in Hawai' $i$ and Brazil; Tetramorium pacificum Mayr is in Florida, Canada, Central America, and the Caribbean; and Odontomacbus simillimus is in the Caribbean (McGlynn 1999).

Dlussky (1994a) classified Pacific ant species using a different system than Wilson and Taylor (1967) and Wilson and Hunt (1967), according to proposed geographical origins, but was not explicit about which species predated human arrival in Polynesia. Dlussky (1994a) classified the 30 wide-ranging Pacific natives of Samoa as two Samoan endemics, two regional endemics, eight species of New Guinean origin, three of Asian origin, 11 pantropical species of Asian origin, three not classified due to taxonomic changes, and one not considered because it was not known from Samoa at the time (Table 2). Again, the two Samoan endemics listed here now should be considered regional endemics due to their greater known ranges.

\section{Exotic Ant Species in Samoa}

According to the classifications of Wilson and Hunt (1967), 26 ant species found in Samoa are alien tramp species not native to the $\mathrm{Pa}$ cific, but brought to the region by human commerce.

Dlussky (1994a) classified the exotic ant species found in Samoa as seven pantropical 
TABLE 2

Native Pacific Ants of Samoa, Plus Known Records from Well-Sampled Locales in the West Pacific and Polynesia

\begin{tabular}{|c|c|c|c|c|}
\hline \multirow[b]{3}{*}{ Species } & \multicolumn{3}{|c|}{ Known Regional Range ${ }^{a}$} & \multirow[b]{3}{*}{ Status $^{b}$} \\
\hline & \multicolumn{2}{|c|}{ West Pacific } & \multirow{2}{*}{$\frac{\text { Polynesia }}{\text { WSTNCFH }}$} & \\
\hline & $\mathrm{AI}$ & MCSNVF & & \\
\hline \multicolumn{5}{|l|}{ Local Endemics } \\
\hline Adelomyrnex samoanus Wilson \& Taylor & -- & $-\ldots+\cdots-\cdots$ & 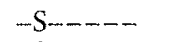 & ES \\
\hline Camponotus flavolimbatus Viehmeyer & -- & ------ & $-\mathrm{S}-----$ & ES \\
\hline +Monomorium sp. & -- & ------ & $-\mathrm{S}-----$ & 0 \\
\hline *Pachycondyla insulana (Mayr) & -- & ------ & $-\mathrm{S}-----$ & ES \\
\hline Pheidole aana Wilson \& Taylor & $\ldots$ & -......- & $-\mathrm{S}-\ldots . . .-$ & ES \\
\hline Pbeidole atua Wilson \& Taylor & -- & ------ & $-\mathrm{S}-----$ & ES \\
\hline Ponera woodwardi Taylor & -- & $\ldots-m-\infty$ & $-S-m m--$ & ES \\
\hline "Pyramica epipola Bolton & -- & ------ & $-\mathrm{S}-----$ & ** \\
\hline Rogeria exsulans Wilson \& Taylor & -- & ----- & $-\mathrm{S}-\ldots---$ & $\mathrm{ES}$ \\
\hline Strumigenys mailei Wilson \& Taylor & -- & $----\mathrm{F}$ & $-\mathrm{S}-----$ & $\mathrm{RE}$ \\
\hline Vollenbovia pacifica Wilson \& Taylor & -- & $-\infty-\infty$ & $-\mathrm{S}-\cdots--$ & ES \\
\hline Vollenhovia samoensis Mayr & -- & ------ & $-\mathrm{ST}----$ & $\mathrm{ES}^{\wedge}$ \\
\hline \multicolumn{5}{|l|}{ Indo-Pacific Natives } \\
\hline Anochetus graeffei Mayr & $\mathrm{AI}$ & MCSNVF & WST-CF- & $\mathrm{PO}$ \\
\hline Camponotus cbloroticus Emery & $-\mathrm{I}$ & MCSNVF & WSTN--- & $\mathrm{PO}$ \\
\hline Camponotus navigator Wilson & -- & $-\mathrm{C}----$ & $-\mathrm{S}-----$ & $\mathrm{ES}^{\wedge}$ \\
\hline Cryptopone testacea Emery & $-\mathrm{I}$ & -CS--- & $-S-\ldots-\ldots$ & OR \\
\hline Eurbopalotbrix procera (Emery) & $\mathrm{AI}$ & $-\mathrm{CS}---$ & $-\mathrm{S}-----$ & OR \\
\hline Hypoponera confinis (Roger) & $-\mathrm{I}$ & $-\mathrm{C}--\mathrm{VF}$ & $-\mathrm{ST}-\mathrm{CF}-$ & PO \\
\hline * Monomorium liliuokalanii Forel & -- & MC---- & -STNCFH & ** \\
\hline Monomorium talpa Emery & $-\mathrm{I}$ & $-\mathrm{CS}-\mathrm{VF}$ & -STNCF- & NG \\
\hline Odontomachus simillimus F. Smith & $-\mathrm{I}$ & MCSNVF & WSTN-F- & $\mathrm{PO}$ \\
\hline Oligomyrmex atomus Emery & $-\mathrm{I}$ & $--\mathrm{S}--\mathrm{F}$ & WST---- & NG \\
\hline Paratrecbina minutula Forel & $\mathrm{AI}$ & $-\mathrm{CS}-\mathrm{VF}$ & $-\mathrm{S}-----$ & PO \\
\hline Pheidole oceanica Mayr & $\mathrm{AI}$ & MCSNVF & WSTNCF- & NG \\
\hline Pheidole sexspinosa Mayr & $-\mathrm{I}$ & $-\mathrm{CS}-\mathrm{V}_{-}$ & WSTN-F- & NG \\
\hline Pheidole umbonata Mayr & $-\mathrm{I}$ & MCSNVF & WSTNCF- & NG \\
\hline Platytbyrea parallela (Smith) & $\hat{A I}$ & M-S--- & $-\mathrm{S}---\mathrm{F}-$ & $\mathrm{OR}$ \\
\hline Ponera incerta (Wheeler) & $-\mathrm{I}$ & $-\mathrm{CS}-\mathrm{V}_{-}$ & $-\mathrm{ST}----$ & $\mathrm{PO}$ \\
\hline Ponera loi Taylor & -- & M----- & $-\mathrm{S}-----$ & $\mathrm{ES}^{\wedge}$ \\
\hline Ponera swezeyi (Wheeler) & -- & ------ & $-\mathrm{S}---\mathrm{FH}$ & $\mathrm{RE}$ \\
\hline Ponera tenuis (Emery) & $-\mathrm{I}$ & MC---- & $-\mathrm{STN}---$ & NG \\
\hline Prionopelta kraepelini Forel & $-\mathrm{I}$ & ------ & $-\mathrm{S}-----$ & PO \\
\hline${ }^{*}$ Rogeria stigmatica Emery & $-\mathrm{I}$ & $-\mathrm{CSNVF}$ & WSTNCF- & $* *$ \\
\hline Solenopsis papuana Emery & $-\mathrm{I}$ & $-\mathrm{CS}--\mathrm{F}$ & WST-CFH & NG \\
\hline Strumigenys godeffroyi Mayr & $\mathrm{AI}$ & MCSNVF & WSTNCFH & PO \\
\hline Strumigenys szalayi Emery & $\mathrm{AI}$ & $-\mathrm{CS}-\mathrm{V}-$ & $-\mathrm{S}-----$ & NG \\
\hline Tapinoma minutum Mayr & $\mathrm{AI}$ & MCS--F & WSTN-F- & PO \\
\hline Tecbnomyrmex albipes (Smith) & $\mathrm{AI}$ & MCSNVF & WSTNCFH & $\mathrm{PO}$ \\
\hline + Tetramorium cf. grassii & -- & ------ & $-S-----$ & o \\
\hline${ }^{*}$ Tetramorium insolens (Smith) & $\mathrm{AI}$ & -CSNVF & WSTN--- & *** \\
\hline Tetramorium pacificum Mayr & $\mathrm{AI}$ & -CSNVF & WSTNCF- & PO \\
\hline Tetramorium tonganum Mayr & $-\mathrm{I}$ & MCS-VF & WSTNCFH & $\mathrm{RE}$ \\
\hline
\end{tabular}

*, Documented by Wilson and Taylor (1967) under a different name.

+ , Not documented by Wilson and Taylor (1967).

" Symbols as in Table 1.

${ }^{b} \mathrm{ES}$, Samoa endemic; ES ${ }^{\wedge}$, changed status due to increased known range; RE, regional endemic; PO, pantropical of Asian origin; OR, Asian origin; NG, New Guinean origin; o, not included in Dlussky (1994a); ${ }^{\star \star}$, taxonomic status changed since Dlussky (1994a). 
TABLE 3

Exotic Ants of Samoa, Plus Known Records from Well-Sampled Locales in the West Pacific and Polynesia

\begin{tabular}{|c|c|c|c|c|}
\hline \multirow[b]{3}{*}{ Exotics } & \multicolumn{3}{|c|}{ Known Regional Range" } & \multirow[b]{3}{*}{ Status $b$} \\
\hline & \multicolumn{2}{|c|}{ West Pacific } & \multirow{2}{*}{$\frac{\text { Polynesia }}{\text { WSTNCFH }}$} & \\
\hline & $\mathrm{AI}$ & MCSNVF & & \\
\hline *Anoplolepis gracilipes (Smith) & AI & MCSNVF & WSTNCFH & $\mathrm{PA} / \mathrm{PO}$ \\
\hline Bracbymyrmex obscurior Forel & -- & $-\cdots---$ & $-\mathrm{S}---\mathrm{H}$ & \\
\hline Cardiocondyla emeryi Forel & $-\mathrm{I}$ & $\mathrm{M}----\mathrm{F}$ & WSTNCFH & PA \\
\hline Cardiocondyla nuda (Mayr) & AI & MCS--F & WSTNCFH & PA \\
\hline +Cardiocondyla obscurior Wheeler & -- & M----- & $-\mathrm{S}--? ? \mathrm{H}$ & o \\
\hline${ }^{*}$ Cerapachys biroi Forel & -- & M----- & $-\mathrm{S}-\cdots--\mathrm{H}$ & $* *$ \\
\hline + Hypoponera opaciceps (Mayr) & -- & $---\mathrm{N}-\mathrm{F}$ & $-\mathrm{ST}-\mathrm{CFH}$ & $\mathrm{PN}$ \\
\hline Hypoponera punctatissima (Roger) & A- & MCSNVF & WSTN-FH & $\mathrm{PA}$ \\
\hline Monomorium destructor (Jerdon) & $\mathrm{AI}$ & M----- & $-\mathrm{S}-\mathrm{NCFH}$ & PA \\
\hline Monomorium floricola (Jerdon) & $\mathrm{AI}$ & MCSNVF & WSTNCFH & $\mathrm{PO}$ \\
\hline Monomorium pharaonis (L..) & $\mathrm{AI}$ & MCS-VF & $-\mathrm{ST}--\mathrm{FH}$ & $\mathrm{PO}$ \\
\hline${ }^{*}$ Monomorizum sechellense Emery & $-\mathrm{I}$ & MC---- & $-\mathrm{ST}-\mathrm{C}-\mathrm{H}$ & $* *$ \\
\hline *Pacbycondyla stigma (Fabricius) & AI & $-\mathrm{CS}--\mathrm{F}$ & $-\mathrm{S}-----$ & PN \\
\hline Paratrecbina bourbonica Forel & -- & MCSN-F & WSTNCFH & PO \\
\hline Paratrechina longicornis (Latr.) & AI & MCSNVF & WSTNCFH & $\mathrm{PO}$ \\
\hline Paratrechina vaga (Nylander) & $\mathrm{AI}$ & MCSN-F & WSTNCFH & PO \\
\hline Pbeidole fervens Smith & $-\mathrm{I}$ & $M C-N-F$ & $-\mathrm{ST}-\mathrm{CFH}$ & $\mathrm{OR}$ \\
\hline Pbeidole megacephala (Fabricius) & AI & $M C--V F$ & WSTNCFH & PA \\
\hline${ }^{*}$ Pyramica membranifera (Emery) & $\ldots \mathrm{I}$ & MCS--F & WST--FH & $\mathrm{PA}$ \\
\hline+ Solenopsis geminzata (Fabricius) & AI & MCSN-F & $-\mathrm{ST}-\mathrm{CFH}$ & $\mathrm{PN}$ \\
\hline${ }^{*}$ Strumigenys emmae (Emery) & $\mathrm{AI}$ & M-SNV- & $-\mathrm{ST}--\mathrm{FH}$ & $\mathrm{PA}$ \\
\hline Strumigenys rogeri Emery & $-\mathrm{I}$ & MCSNVF & WSTN-FH & PA \\
\hline Tapinoma melanocephalum (Fabricius) & AI & MCSNVF & WSTNCFH & PO \\
\hline${ }^{\star}$ Tetramorium bicarinatum (Nylander) & AI & MCSNVF & WST-CFH & $* *$ \\
\hline + Tetramorium lanuginosum Mayr & $\mathrm{AI}$ & MCS--- & WST-CF- & $\mathrm{PO}$ \\
\hline Tetramorium simillimum (Smith) & AI & MCSNVF & WSTNCFH & PA \\
\hline
\end{tabular}

"Symbols as in Table 1.

$b$ PA, pantropical of African origin; PN, pantropical of neotropical origin; $\mathrm{PO}$, pantropical of Asian origin; $\mathrm{OR}$, Asian origin; $\mathrm{o}$, not included in Dlussky (1994a); ${ }^{\star *}$, taxonomic status changed since Dlussky (1994a).

species of Asian origin, 10 pantropical species of African origin, four pantropical species of neotropical origin, and one species of Asian origin, three not classified due to taxonomic changes, and one not considered because it was not known from Samoa at the time (Table 3). Although Wilson and Taylor (1967) and Dlussky (1994a) considered Anoplolepis gracilipes to be from Africa, this species is more likely to be native to tropical Asia (J.K.W., unpubl. data).

It is striking that only four exotic ant species in Samoa are of New World origin: Bracbymyrmex obscurior Forel, Hypoponera opaciceps, Pacbycondyla stigma (Fabricius), and Solenopsis geminata. This, no doubt, relates to not only geographic proximity and ocean currents but also traditional trade routes. Certainly in the future, more arrivals of ants from the New World can be expected.

\section{Future of the Samoan Ant Fauna}

A number of widespread native and exotic ants known from the Pacific have not yet been recorded from Samoa (e.g., Plagiolepis alluaudi Emery known from many parts of the Pacific, including Samoa's neighbors Tonga, Niue, and the Cook Islands). One destructive tramp ant known in the Pacific that has not yet been found in Samoa is Wasmannia auropunctata (Roger). Wasmannia auropunctata, native to the neotropics, has become established in several Pacific island groups, in- 
cluding the Galápagos (Clark et al. 1982), Wallis and Futuna (Gutierrez 1981 in Jourdan 1997), New Caledonia (Jourdan 1997), the Solomon Islands (Fabres and Brown 1978), and most recently Vanuatu (Rapp 1999) and Hawai'i (Anonymous 1999). In areas where it invades, Wasmannia auropunctata can be an important agricultural pest, both due to its painful sting and through enhancing populations of Homoptera (Spencer 1941). In addition, Wasmannia auropunctata has direct negative impacts on native invertebrates and vertebrates (Fabres and Brown 1978, Lubin 1984, Jourdan 1997, Wetterer 1997b, Wetterer et al. 1999).

The ants of Samoa are perhaps the beststudied ant fauna in the Pacific. Still, we do not believe that our list is complete. We expect that more endemic Samoa ant species await discovery, particularly in the relatively unexplored and undisturbed highlands of Savai'i, Tutuila, and Ta'u.

\section{ACKNOWLEDGMENTS}

We thank Stefan Cover for identifying the ants; Edward O. Wilson for advice and encouragement, and for financing the mounting of ant specimens; Mingsheng Wang for mounting the ants; Andrea Wetterer, Margaret Wetterer, and Scott Miller for comments on the manuscript. Most of the geographic data came from the UN Environment Programme Islands Web Site (UNEP 1998).

\section{Literature Cited}

Anonymous. 1999. New stinging little fire ant found on the Big Island and Kauai. NASDA (Natl. Assoc. State Dep. Agric.) News 7:1.

Bolton, B. 1976. The ant tribe Tetramoriini (Hymenoptera: Formicidae): Constituent genera, review of smaller genera and revision of Triglyphotbrix Forel. Bull. Br. Mus. Nat. Hist. Entomol. 34:281-379.

. 1977. The ant tribe Tetramoriini

(Hymenoptera: Formicidae): The genus Tetramorium Mayr in the Oriental and Indo-Australian regions, and in Australia.
Bull. Br. Mus. Nat. Hist. Entomol. 36:67151.

- 1987. A review of the Solenopsis genus-group and revision of Afrotropical Monomorium Mayr (Hymenoptera: Formicidae). Bull. Br. Mus. Nat. Hist. Entomol. 54:263-452.

1995. A new general catalogue of the ants of the world. Harvard University Press, Cambridge, Massachusetts.

. 2000. The ant tribe Dacetini. Mem. Am. Entomol. Inst. (Gainesville) 65:11028.

Buxton, P., and G. H. E. Hopkins. 1927. Research in Polynesia and Melanesia: An account of investigations in Samoa, Tonga, the Ellice group, and the New Hebrides, in 1924, 1925. Parts I-TV (relating principally to medical entomology). London School of Hygiene and Tropical Medicine, London.

Clark, D. B., C. Guayasamin, O. Pazamino, C. Donoso, and Y. Paez de Villacis. 1982. The tramp ant Wasmannia auropunctata: Autecology and effects on ant diversity and distribution on Santa Cruz Island, Galapagos. Biotropica 14:196-207.

Dlussky, G. M. 1994a. Zoogeography of southwestern Oceania. Pages 48-93 in Y. G. Puzatchenko, S. I. Golovatch, G. M. Dlussky, K. N. Diakonov, A. A. Zakharov, and G. A. Korganova, eds. Animal population of the islands of southwestern Oceania (ecogeographic studies). Nauka Publishers, Moscow. (In Russian.)

- 1994b. Ants (Hymenoptera: Formicidae) of Fiji, Tonga, and Samoa and the problem of formation of island fauna. 2. Tribe Dacetini. Entomol. Rev. 73:110122 [translated from Zool. Zh. 72 (6): 52$65,1993]$.

-. 1994c. Ants (Hymenoptera, Formicidae) of Fiji, Tonga, and Samoa and the problem of formation of island fauna 2 . Tribe Dacetini. Entomol. Rev. 73:110122 [translated from Zool. Zh. 72:66-76, 1993].

Fabres, G., and W. L. Brown Jr. 1978. The recent introduction of the pest ant Wasmannia auropunctata into New Caledonia. J. Aust. Entomol. Soc. 17:139-142. 
Jourdan, H. 1997. Threats on Pacific islands: The spread of the tramp ant Wasmannia auropunctata (Hymenoptera: Formicidae). Pac. Conserv. Biol. 3:61-64.

Kami, K. S., and S. E. Miller. 1998. Samoan insects and related arthropods: Checklist and bibliography. Bishop Mus. Tech. Rep. $13: 1-121$.

Lubin, Y. D. 1984. Changes in the native fauna of the Galápagos Islands following invasion by the little red fire ant, Wasmannia auropunctata. Biol. J. Linn. Soc. 21:229-242.

Mann, W. M. 1935. Two new ants collected in quarantine. Psyche (Camb.) 42:35-37.

Mayr, G. 1876. Die australischen Ameisen. J. Mus. Godeffroy Hamburg 12:56-115.

McGlynn, T. P. 1999. The worldwide transfer of ants: Geographical distribution and ecological invasions. J. Biogeogr. 26:535548.

Morrison, L. W. 1996a. Community organization in a recently assembled fauna: The case of Polynesian ants. Oecologia (Berl.) 107:243-256.

. 1996b. The ants (Hymenoptera: Formicidae) of Polynesia revisited: Species numbers and the importance of sampling intensity. Ecography 19:73-84. 1997. Polynesian ant (Hymenoptera: Formicidae) species richness and distribution: A regional survey. Acta Oecol. 18:685-695.

Rapp, G. 1999. Introduction of the fire ant Wasmannia auropunctata into Vanuatu. Agric. Alert 18:1.

Santschi, F. 1919. Cinq notes myrmécologiques. Bull. Soc. Vaudoise Sci. Nat. 52:325-350.

. 1928. Formicidae (Formis). Insects Samoa 5:41-58.

Spencer, H. 1941. The small fire ant Wasmannia in citrus groves - a preliminary report. Fla. Entomol. 24:6-14.
Taylor, R. W. 1967a. A monographic revision of the ant genus Ponera Latreille (Hymenoptera: Formicidae). Pac. Insects Monogr. 13:1-112.

. 1967b. Entomological survey of the Cook Islands and Niue. 1. Hymenoptera -Formicidae. N. Z. J. Sci. 10:1092-1095.

Terayama, M., S. Miyano, and T. Kurozumi. 1994. Ant fauna (Insecta: Hymenoptera: Formicidae) of the Northern Mariana Islands, Micronesia. Pages 231-236 in A. Asakura and T. Furuki, eds. Biological expedition to the Northern Mariana Islands, Micronesia. Nat. Hist. Res., Spec. Issue, No. 1. Nat. Hist. Mus. Inst., Chiba, Japan. UNEP. 1998. United Nations Environment Programme Islands Web Site. Nairobi, Kenya (www.unep.ch/islands/isldir.htm).

Wetterer, J. K. 1997a. Ants on Cecropia in Hawaii. Biotropica 29:128-132.

. 1997b. Alien ants of the Pacific islands. Aliens 6:3-4.

. 1998. Nonindigenous ants associated with geothermal and human disturbance in Hawai'i Volcanoes National Park. Pac. Sci. $52: 40-50$.

. 2002. Ants of Tonga. Pac. Sci. 56:125-135.

Wetterer, J. K., P. D. Walsh, and L. J. T. White. 1999. Wasmannia auropunctata (Roger) (Hymenoptera: Formicidae), a highly destructive tramp ant, in wildlife refuges of Gabon, West Africa. Afr. Entomol. 7:292-294.

Wheeler, W. M. 1935. Check list of the ants of Oceania. Occas. Pap. Bernice Pauahi Bishop Mus. 11:1-56.

Wilson, E. O., and G. L. Hunt. 1967. Ant fauna of Futuna and Wallis Islands, stepping stones to Polynesia. Pac. Insects 9:563-584.

Wilson, E. O., and R. W. Taylor. 1967. Ants of Polynesia. Pac. Insects Monogr. 14:1109. 